\title{
Car park designers' handbook
}

\author{
Jim Hill
}

With contributions from

Glynn Rhodes, Steve Vollar and Chris Whapples 
Published by Thomas Telford Publishing, Thomas Telford Ltd,

1 Heron Quay, London E14 4JD.

URL: http://www.thomastelford.com

Distributors for Thomas Telford books are

USA: ASCE Press, 1801 Alexander Bell Drive, Reston, VA 20191-4400, USA

Japan: Maruzen Co. Ltd, Book Department, 3-10 Nihonbashi 2-chome, Chuo-ku, Tokyo 103

Australia: DA Books and Journals, 648 Whitehorse Road, Mitcham 3132, Victoria

First published 2005

Also available from Thomas Telford Books

The Motorway Achievement volume 1. The British motorway system: visualisation, policy and administration. Edited by Sir Peter and Robert Baldwin. ISBN 0727731963

The Motorway Achievement volume 2. Frontiers of knowledge and practice.

Edited by Professor Ron Bridle and John Porter

A catalogue record for this book is available from the British Library

ISBN: 0727734385

(C) Thomas Telford Limited 2005

All rights, including translation, reserved. Except as permitted by the Copyright, Designs and Patents Act 1988, no part of this publication may be reproduced, stored in a retrieval system or transmitted in any form or by any means, electronic, mechanical, photocopying or otherwise, without the prior written permission of the Publishing Director, Thomas Telford Publishing, Thomas Telford Ltd, 1 Heron Quay, London E14 4JD.

This book is published on the understanding that the authors are solely responsible for the statements made and opinions expressed in it and that its publication does not necessarily imply that such statements and/or opinions are or reflect the views or opinions of the publishers. While every effort has been made to ensure that the statements made and the opinions expressed in this publication provide a safe and accurate guide, no liability or responsibility can be accepted in this respect by the authors or publishers.

Typeset by Academic + Technical, Bristol

Printed and bound in Great Britain by MPG Books, Bodmin, Cornwall 
This book is dedicated to the memory of John Charles Cannon

MA (Cantab), CEng, MICE, FIStructE

$1931-2005$

An outstanding engineer who, for 50 years, fought the effects of poliomyelitis with courage and determination. 


\section{Contents}

Foreword xi

Preface xiii

Glossary of terms xiv

Acknowledgements xvi

1 Introduction 1

1.1 Historical note 1

1.2 Advice and guidance 2

1.3 Scope 2

1.4 Design flexibility 2

2 Design brief 4

2.1 The client 4

2.2 The brief 4

3 Design elements 6

3.1 The standard design vehicle (SDV): discussion 6

3.1.1 Length and width 6

3.1.2 Height 6

3.1.3 Wheelbase 7

$\begin{array}{lll}3.1 .4 & \text { Ground clearance } & 7\end{array}$

3.1.5 Turning dimensions 8

3.1.6 Recommended minimum diameters for turns up to $180^{\circ}$ between obstructions 8

3.1.7 Left side, right side or in the middle? 8

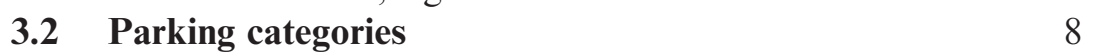

3.2.1 Discussion 8

3.2.2 Car park categories 9

3.3 Parking stalls 9

3.3.1 Discussion 9

3.3.2 Recommended dimensions for differing parking categories

3.3.3 Obstructions between stalls 9

3.3.4 Angled parking 10

$\begin{array}{lll}3.4 & \text { Aisle widths } & 10\end{array}$

3.4.1 Discussion 10

3.4.2 One-way-flow with reduced aisle widths $\quad 11$

3.4.3 Two-way-flow-with reduced aisle widths $\quad 12$

3.4.4 Manoeuvring on aisles 13

3.4.5 Turning between aisles 13

3.5 Bin dimensions 13

3.5.1 Discussion 13

3.5.2 Recommended minimum bin dimensions for parking with $2.400 \mathrm{~m}$-wide stalls $\quad 13$

3.6 Ramps and access-ways 13

3.6.1 Discussion 13

3.6.2 Recommended maximum vehicle gradients $\quad 16$

3.6.3 Transitional slopes 17

$\begin{array}{ll}\text { 3.6.4 Ramp projections into aisles } & 17\end{array}$

$\begin{array}{lll}\text { 3.6.5 Storey height ramps } & 17\end{array}$ 
$\begin{array}{lll}3.6 .6 & \text { Side clearance } & 17\end{array}$

3.6.7 Manoeuvring envelope 18

3.6.8 Stall access 20

3.6.9 One-way-flow ramp widths: discussion 20

3.6.10 Ramp widths and angled parking 21

3.6.11 Two-way-flow ramps 21

3.6.12 Turning circle templates 22

3.6.13 Two-way-flow: recommended minimum clear ramp widths 22

3.6.14 Scissors-type ramps 22

3.6.15 Side-by-side ramps 22

3.6.16 Circular ramps 22

3.6.17 Recommended minimum diameters for full
circle ramps between limiting wall faces

3.6.18 Recommended minimum widths for circular
ramp lanes between wall faces

3.7 Interlocking ramps 24

3.7.1 Stadium type 24

3.7.2 Circular type $\quad 24$

3.8 Kerbs 24

3.9 Super-elevation 25

3.10 Parking deck gradients 25

3.11 Headroom and storey heights 25

3.12 Height limitations 25

4 Dynamic considerations 26

4.1 Discussion 26

4.1.1 Impact speeds 26

4.1.2 Effects of rain 26

4.1.3 Exit and entry rates and internal movement 26

4.1.4 Dynamic capacities for different stall widths and categories 27

4.1.5 Stopping distance $\quad 27$

4.1.6 Speed limits 27

4.1.7 Dynamic capacities of ramps and access-ways 27

4.1.8 Dynamic capacities of cross-ramps and
access-ways, per hour

4.1.9 Dynamic capacities of parking decks; calculations 28

4.1.10 Dynamic efficiency 29

5 Static considerations 30

5.1 Static efficiency, discussion 30

5.1.1 Relative efficiencies 30

5.1.2 Area per car space 31

5.1.3 Recommended capacities 31

6 Circulation design 33

6.1 Discussion 33

6.2 How many levels?

6.3 Roof considerations 33

6.4 Circulation efficiency 34

6.4.1 Discussion 34

6.4.2 Shortest travel distance 34

6.4.3 Examples of circulation efficiency 35

6.5 Parking times 35

6.5.1 Discussion 35 
7 Circulation layouts $\quad 37$

$\begin{array}{lll}7.1 & \text { Discussion } & 37\end{array}$

7.2 Dimensions used 37

$\begin{array}{lll}\mathbf{7 . 3} & \text { User-friendly features } & \mathbf{3 7}\end{array}$

7.3.1 Discussion $\quad 37$

$\begin{array}{lll}\text { 7.3.2 Simplicity } & 37\end{array}$

7.3.3 Crossovers 38

7.3.4 Circulation direction 38

7.3.5 Dead ends (culs-de-sac) 38

7.4 Angled and right-angled parking: a comparison 38

7.5 Split-level decks (SLDs) 43

SLD 1 One-way traffic flow with an included rapid outflow route 44

SLD 2 One-way traffic flow with an excluded rapid outflow route 46

SLD 3 One-way-flow with side-by-side ramps

SLD 4 Combined one-way-flows, three bins or
more wide

SLD 5 Combined one- and two-way-flows, three bins or more wide 52

SLD 6 Two-way-flow with 'combined' ramps 54

SLD 7 One-way-flow with an included contra-flow rapid exit route 56

7.6 Sloping parking decks (SDs) 59

SD 1 Single helix with two-way-flow 60

SD 2 Single helix with one-way-flow and a rapid outflow route

SD 3 Double helix, end connected with one-way-flow on the central access-way 64

SD 4 Double helix, end connected with two-way-flow on the central access-way 66

SD 5 Interlocking double helix, with one-way-flows 68

SD 6 Combined helix, side connected with one- and two-way-flows

SD 7 and 8 Double helix, side connected, with

one-way-flows $\quad 72$

7.7 Combined flat and sloping deck (FSD) layouts 75

FSD 1 Single helix with two-way-flow 76

FSD 2 Single helix with one-way-flow and a rapid outflow route 78

FSD 3 Combined helix, side connected with one- and two-way-flows

FSD 4 Combined helix, side connected with one-way-flow

FSD 6 and 7 Double helix, side connected with one-way traffic flows

FSD 8 Single helix with one-way-flow and an internal ramp

7.8 Combined flat and sloping deck layouts with internal cross-ramps (VCM and WPD)

VCM 1 One-way-flow with two one-way-flow ramps

VCM 2 One-way-flow with end ramps

VCM 3 Two-way-flow with a single end ramp

VCM 4 One- and two-way traffic flows with a single ramp 
WPD 1 Warped parking decks with one-way-flow

7.9 Flat decks with storey height internal ramps (flat with internal ramps - FIR)

FIR 1 One-way-flow decks with combined two-way-flow ramps at right-angles to the aisles

FIR 2 One-way-flow decks with side-by-side (scissors type) ramps at right-angles to the aisles

FIR 3 One-way-flow decks with combined two-way-flow ramps parallel with the aisles

FIR 4 One-way-flow decks with separated one-way-flow ramps

7.10 Minimum dimension (MD) layouts

MD 1 One-way-flow between circular end ramps 114

MD 2 Two-way-flow with a circular ramp at one end 116

MD 3, 4 and 5 One- and two-way-flows, ten stalls wide

MD 6, 7 and 8 One- and two-way-flows eight stalls wide (VCM type)

MD 9, 10 and 11 One- and two-way-flows eight stalls wide (split-level type)

7.11 Circular sloping decks (CSDs)

CSD 1 Circular parking deck with two-way-flow

7.12 Half external ramps (HERs)

HER 1 Half spiral with one-way-flow

HER 2 and 3 Straight ramps with one-way-flow

HER 4 Straight ramps with one-way-flow, end located

HER 5 Straight ramps with one-way-flow, end located

7.13 External ramps (ERs)

ER 2 Full circular ramps each with a one-way traffic flow

ER 3 Straight ramps with a one-way traffic flow 144

ER 4 Storey height, straight ramps 146

ER 5 Stadium-shaped interlocking ramps 148

ER 6 Circular interlocking ramps 150

8 Stairs and lifts 153

8.1 Discussion 153

8.2 Vertical and horizontal escape 153

8.2.1 Stairs, widths of flights 153

8.2.2 Vertical escape 155

8.2.3 Horizontal escape 155

8.3 Escape distances 155

$\begin{array}{lll}8.4 & \text { Lift sizing } & 156\end{array}$

9 Disabled drivers and carers 161

9.1 Discussion 161

9.2 Stall locations 161

9.3 Stall dimensions 162

9.4 Access 163

10 Cycles and motorcycles $\quad 165$

$\begin{array}{lll}10.1 & \text { Discussion } & 165\end{array}$

$\begin{array}{ll}10.2 \text { Cycle parking } & 165\end{array}$ 
10.3 Motorcycle parking 165

10.4 Lockers 166

10.5 Fiscal control 167

11 Security 169

$\begin{array}{lll}11.1 & \text { Discussion } & 169\end{array}$

11.2 Lighting, music and CCTV 169

$\begin{array}{ll}11.3 \text { See and be seen } & 170\end{array}$

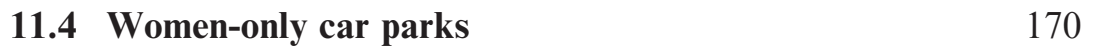

12 Underground parking 173

$\begin{array}{ll}\text { 12.1 Discussion } & 173\end{array}$

13 Lighting 175

13.1 Discussion 175

13.2 Emergency lighting 175

14 Signage 177

14.1 Discussion 177

14.2 Directional signs 177

14.3 Information signs 178

14.4 Variable message sign systems 178

14.5 Emergency signs 179

15 Drainage 181

15.1 Discussion 181

16 Fire escapes, safety and fire fighting 183

16.1 Discussion 183

16.2 Escape distances 183

16.3 Fire safety 183

16.4 Fire-fighting measures 183

16.5 Sprinklers 184

16.6 Fire escapes 184

17 Fiscal and barrier control 187

$\begin{array}{lll}17.1 & \text { Discussion } & 187\end{array}$

$\begin{array}{ll}\text { 17.2 Control systems } & 187\end{array}$

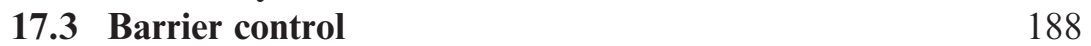

18 Ventilation 191

18.1 Discussion 191

18.2 Natural ventilation requirements 191

18.3 Mechanically assisted natural ventilation requirements 191

18.4 Mechanical ventilation requirements 191

19 Structure 195

19.1 Discussion 195

19.2 Construction materials 195

19.3 Joints 196

19.4 Perimeter protection 196

19.5 Concrete finishes 197

19.6 Protective coatings 197

19.7 Waterproofing 197

19.8 Cambers 198

20 Appearance 201 
20.1 Discussion

20.2 Appearance requirements

Appendix A

References

Index 


\section{About the authors}

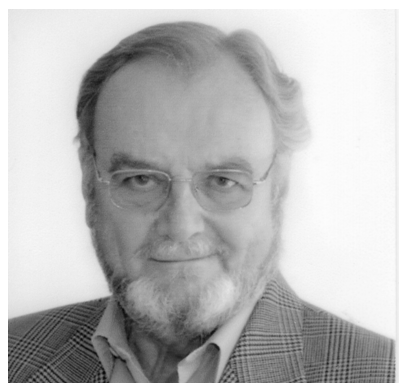

James Hill CEng

FIStructE (ret'd)

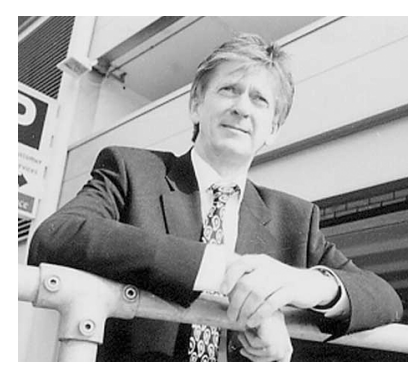

Glynn Rhodes BSc (Hons) CEng MICE MIHT FConsE

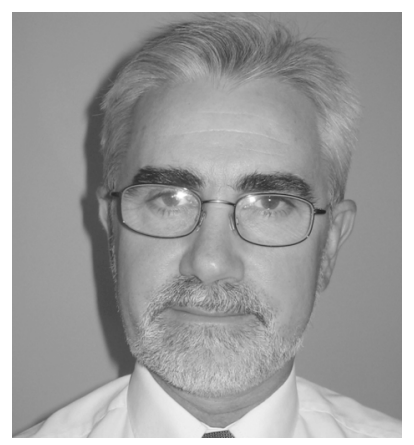

Stephen Vollar Eur Ing BSc CEng FIStructE MICE FConsE

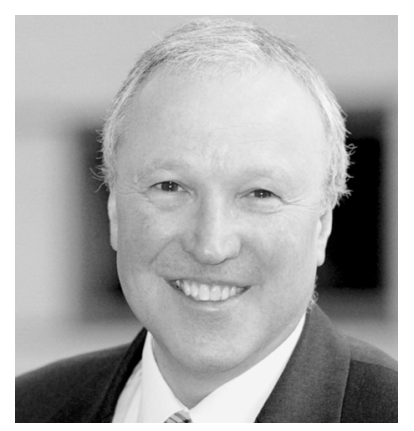

Christopher Whapples BSc (Hons) CEng FIStructE FICE MIHT FConsE
In 1967 Jim founded the Hill Cannon Partnership (HCP) with John Cannon and has been involved in car park design since 1969. In 1970, they developed the Tricon structural system and in $1993 \mathrm{Jim}$ patented the Vertical Circulation Module system (VCM). He is a past President of the British Parking Association and a regional Chairman of the Concrete Society. He is now a consultant to the practice, having retired in 1992, since when he has concentrated on the further development of VCM, designing appropriate circulation layouts for many projects and researching this book. He is currently writing a similar handbook on 'good practice' parking in the USA.

Glynn is a senior partner of the HCP and has been involved in the design of 30 multi-storey car parks since 1986, two of which have been voted Best New Build car parks at the annual British Parking Awards. He also received the Ernest Davies Award for the best article published in Parking News entitled 'Current Trends in the Design of Car Parks'. He has provided design advice for large underground car parking facilities in Manila, Kuala Lumpur (Petronas Towers), Zagreb and Dubai. Recent projects include the Jubilee car park in Harrogate (precast with 450 spaces), Merryhill Shopping Centre, West Midlands (precast with 1600 spaces) and Manchester Royal Infirmary (precast with 1600 spaces).

Steve is a senior partner of the HCP and has been actively involved with car park design and parking related subjects since 1996: these include structured car parks, both above and below ground, as well as large capacity single deck layouts. His particular interest is in the provision of suitably located parking for disabled drivers, two wheeled traffic and general 'wayfinding' for both motorists and pedestrians alike. Recent design projects include Birmingham Airport (precast with 1700 spaces), Ocean Terminal; Edinburgh (precast with 1000 spaces) and Clarence Dock; Leeds (precast with 1600 spaces).

A senior partner of the HCP, Chris has been involved in the design of parking structures for more than twenty years. He is a contributor to the IStructE publication Design recommendations for multi-storey and underground car parks and the Institution of Civil Engineers' publication Recommendations for inspection, maintenance and management of car park structures. He has served on European technical committees and has presented papers on parking related subjects. His particular interest is in the development of new structural forms. Recent design projects include St. Andrews; Norwich (steel frame with 1100 spaces), Sundials; Amersham (steel frame with 550 spaces) and Designer Outlet Village, Livingston (in situ with 1600 spaces). 
Jim Hill has spent the last 35 years in the development of car park design and this experience has given him a unique insight into the reasons why some buildings operate successfully and others, of a similar size and activity, do not. The choice of the correct circulation layout is a subject that he considers to be of prime importance in the creation of an efficient parking building.

Both as a consumer of parking services and a former parking manager, it always intrigues me why some parking layouts are easily navigated and yet others test one's patience? As an engineer, I think logically and admire the 'art of parking' created by my fellow colleagues; as a consumer I want to be able to park my car as quickly and as effectively as I can and get on with the business in hand, be it work or play; this is especially true if I have children with me.

My experience has taught me that parking is a means to an end; it is the first and last impression of my 'destination'; it needs to be good if I'm to contemplate returning there again and again. This is especially true in the retail and commercial world where (hopefully) my custom is valued. It is equally true when I visit an unfamiliar town or city, park at a rail station, or simply spend a day at leisure someplace.

Equally important is the need to feel intuitively safe and welcome wherever I choose to park. Complex layouts, frustration with queues and conflict with others who are manoeuvring about in or out of parking spaces, or sometimes in what seems like a never-ending set of twists and turns to get in or out of the car park in the first place, only serve to increase my sense of 'uncared for' by the owner or operator.

This book, describes and illustrates some $60+$ variations on the many 'layout themes', no doubt there are others. Their advantages and disadvantages are discussed, recommendations made for their practical application and suggestions made for other layouts that should also be considered.

More than just discussing layouts, the author has shown how ramps can be prevented from projecting excessively into traffic aisles, how to assess dynamic capacity and efficiency, and the many other considerations that go to make up the design process. The matters dealt with in Chapters 8 to 20 such as the current requirements for people with mobility impairments, pedestrian access, security, ventilation, etc. have been written with the help of his partners, all parking experts in their own right.

In the author's opinion, effective design is based upon common sense, a little crystal ball gazing and experience: it is not a precise art. He suggests that, provided drivers will want to frequent the car park and clients are willing to pay for it, little else matters. I wouldn't want to disagree with him, but my comments about being 'welcome' at any parking facility are the key to its success. If the operator wants to do business, good customer service is vital; to do that needs good design.

This book addresses the subject of car park design, especially the design of circulation layouts, in a practical manner and can be easily 
understood by anyone with an interest in the subject. It will help to identify examples of best practice in making our parking facilities more accessible to all. The book is also a useful reference for those considering the Park Mark ${ }^{\circledR}$ Safer Parking Scheme.

\section{Kelvin Reynolds}

Kelvin is Director of Technical Services at the British Parking Association and Head of the Safer Parking Scheme. 


\section{Preface}

Information on the design of vehicle circulation systems in car parks is hard to find: had it not been so this book, probably, would not have been written. To my knowledge, special features and relative efficiencies of car parks have never before been discussed in any great detail. Many designers are unaware of the advantages of using a particular layout system over another and it is a major purpose of this book to redress that imbalance.

In 1968, John Cannon and I first became involved in car park structures when we were retained to design the foundations and nonstandard elements for a proprietary precast concrete system. A local car park incorporating this system had become the subject of adverse comment by many who used it, convincing us that we could do better ourselves. Our first effort was to develop a clear-span structure that was efficient, economical, aesthetically pleasing and capable of being constructed using structural steel as well as precast and cast in situ concrete: this was a successful venture and after more than 35 years it is still being used in many car park designs. In time, however, it became clear that no matter how efficient the structural solution was and how attractive the architectural appearance, if it was wrapped around a poor choice of circulation layout the result was yet another unpopular car park. In many under-used car parks, the reason for their unpopularity is not that that they have been allowed to become dirty and/or dingy (conditions that by themselves would not normally put off most motorists), but rather that they suffered from a poor choice of internal layout. Of the many buildings inspected, the most unpopular have, invariably, incorporated inappropriate circulation designs. Rather than giving these car parks an expensive cosmetic 'makeover', the money would have been better spent on improving the layout, even at the cost of losing, possibly, a few parking stalls.

Over the years, as we became more experienced, so our awareness of the number of different layouts available increased. Fifteen years ago I decided to list them and recommend when and where they could be put to best use. This endeavour was interrupted in 1992 by the development and promotion of the vertical circulation module (VCM) circulation system. It was just as well, as the number of different layouts has risen even further since then. Some have been rejected as being impractical or just plain whimsical, but those that are featured in this book are practical and have been constructed somewhere but not always in the UK. With more than 6000 car parks in the UK, 30000 in the USA and many thousands more in the rest of the world, it is unlikely that all of the possible variations will have been covered, and if any reader is aware of a practical circulation layout substantially different from those featured and lets me know, if it is included in a future edition they will be acknowledged as the source.

Finally, I would like to thank my wife Rosalie who not only accompanied me on my travels around the car parks of several countries without complaint, but was also of invaluable assistance in suggesting improvements to the text and correcting my grammatical errors: any that remain are entirely my own fault. 


\section{Glossary of terms}

\section{Access-way or crossway}

A traffic lane without adjoining stalls laid flat or to a slope not exceeding $5 \%$, also capable of being used by pedestrians.

\section{Aisle}

A traffic lane with adjoining stalls on one or more sides.

\section{Bin}

Used to denote the dimension across an aisle and its adjacent stalls. (A half bin has stalls only on one side.)

\section{Circulation efficiency}

A method of comparing the travel distance required to search the stalls, in any particular car park, with the minimum travel distance. (Given as a percentage.)

\section{Congestion}

Applies to traffic that is unable to flow freely.

\section{Cross-ramp}

An inclined traffic lane connecting the aisles in adjacent bins, laid to a slope greater than $5 \%$.

\section{Deck}

A single floor that extends over the plan area of a parking building.

\section{Des Recs}

A shortened form of words describing the Design Recommendations for Multi-storey and Underground Car Parks, 3rd edition, published in June 2002 by the Institution of Structural Engineers.

\section{Dynamic capacity}

A measure of the rate that traffic can pass a given location within a car park. (Given in vehicles per hour.)

\section{Dynamic efficiency}

A measure of the ability of a car park to process vehicles under normal operating conditions.

\section{Excluded}

Applies to an inflow route that is separated from an outflow route.

\section{Extended}

Applies to any traffic route that is not rapid.

\section{Included}

A flow route that is located within the circulation pattern of another.

\section{Inflow}

Applies to the search path for traffic within a car park. 


\section{Manoeuvring envelope (ME)}

The boundaries established by the minimum turning circle when entering a crossway or ramp, outside of which a vehicle is unable to manoeuvre without reversing.

MPV

The initials for a multi-purpose vehicle.

\section{MSCP}

The initials for a multi-storey car park.

\section{One-way-flow}

Traffic flowing in a single direction on an aisle.

\section{Outflow}

Applies to traffic exiting from a car park.

\section{Ramp}

Any traffic lane, without adjoining stalls, that provides access to or from parking at different levels.

\section{Rapid}

Applies to a short route for inflow or outflow traffic.

\section{Stall}

The parking area allotted to a single vehicle, exclusive of any other adjoining area.

\section{Stall pitch}

The spacing for stalls, normal to an aisle, for a particular angle of parking.

\section{Static capacity}

The total number of stalls contained within a designated area or complete car park.

\section{Static efficiency}

The area of the parking decks divided by the static capacity and given as an area per stall.

\section{SUV}

The initials for a sports utility vehicle.

\section{Swept path}

The width on plan established by a vehicle for any given radius of turn.

\section{Two-way-flow}

Traffic flowing in both directions on an aisle, ramp or crossway.

Vph

Vehicles per hour. 


\section{Acknowledgements}

Figs 1.1, 3.1, 3.2, 3.3, 3.5(a) and (b), 3.7, 3.8, 3.9, 3.10, 3.11, 3.17, 3.19, $3.20,6.1,7.2,7.3,7.5,7.7,7.8,7.9,8.1,9.1,10.1(\mathrm{a}), 11.1,12.1,13.1$, 14.1, 15.1, 16.1, 17.1, 19.1 and 20.1 Hill-Cannon archives.

Figs 7.4 and 7.6 courtesy of Dundec Ltd.

Fig. 7.10 courtesy of Norwest Holst.

Fig. 10.2(c) courtesy of Falco.

Fig. 10.3(d) courtesy of Motoloc Ltd.

Fig. 18.17 courtesy of PSB (UK) Ltd. 